\title{
Understanding bats as a host of different viruses and Nepal's vulnerability on bat viruses
}

\author{
Pushpa Raj Acharya ${ }^{1}$ (I) Kishor Pandey ${ }^{2 *}$ (i) \\ ${ }^{1}$ Central Campus of Science and Technology (CSST), Faculty of Science and Technology, Mid-western University, Surkhet, Nepal \\ ${ }^{2}$ Central Department of Zoology, Institute of Science and Technology, Tribhuvan University, Kathmandu, Nepal \\ *Correspondence: kishor.pandey@cdz.tu.edu.np
}

Received: 06 October 2020 | Revised: 10 December 2020 | Accepted: 10 December 2020

\begin{abstract}
Bats maintain and transmit many viruses (Filoviruses, Rubulaviruses, Henipaviruses, Lyssaviruses, and Coronaviruses etc.); most of them are pathogenic to human but bats act as reservoir host without causing any pathogenesis. Coronavirus disease-2019 (COVID-19) pandemic is a twenty-first-century awakening for the human world that signifies the zoonotic viral challenge. Bats fauna are suspected to originate viral outbreaks through solid evidence that is lacking worldwide. The bats like Pteropus giganteus, Rousettus leschenaultii, Eonycteris spealea, Rhinolophus sinicus, $R$. affinis, $R$. ferremequinum, Nyctalus noctula, and Scotophillus sp. are reported for viral evidence that are also extended to Nepal's geography. Bats bush-meat culture persist in Chepang community of Nepal indicates a high risk of a zoonotic viral outbreak in the future. Though Nepal has no evidence of any viral outbreak until the COVID-19 pandemic situation, precaution is warned for bat conservation and bat roost management to ensure bat virus safety.
\end{abstract}

Keywords: Bat virus, Bushmeat, COVID-19, Nepal, Zoonotic

\section{1 | Introduction}

Viruses were discovered at the end of the $19^{\text {th }}$ century as important agents causing infectious diseases of animals and plants (Rott \& Siddell 1998). They are small particles that depend on genomic materials (DNA or RNA). They use genomic contains to facilitate dispersal. The evolution of viruses is determined by the environment that they occupy. They have both general and specific requirements for replication and existence. All viruses require the use of host cell's ribosomes, nucleotides, ATP, and amino acid resources. The abundance and diversity of viruses depend upon the host ecology, feeding habits, sexual behavior, etc. Viruses with high contagious rates are able to invade novel hosts at lower host population densities and present continuously in susceptible hosts (Anderson \& May 1992, Shostak 2003). Conversely, viruses with lower transmission rates would only able to invade at high host contact rates and present at high host densities (Smith et al. 2014). In some viruses (Sexually transmitted virus) the transmission rate is independent of host density (Shostak 2003).
Viral the outbreak is not new to the human community. Generally, viruses are grouped into two categories- RNA virus and DNA virus. RNA virus and virions can cause $80-90 \%$ of all virus-related diseases in humans. An RNA virus is more pathogenic and they have hyper-mutable traits than the DNA virus. As the RNA viruses don't have DNA polymerase in their genome, they have less proofreading. Bats act as rich reservoirs host for the 23 families of viruses including double-stranded DNA viruses, singlestranded DNA viruses, and positive- and negative-sense singlestranded RNA virus (Hayman 2016). Bats are sources of medical and veterinary important virus family including rabies-causing lyssaviruses, coronaviruses, henipaviruses, paramyxoviruses (causing mumps), reoviruses, and filoviruses (causing Ebola) (Drexler et al. 2012, Guo et al. 2013, Tong et al. 2012).

Bats are unique among mammals having true and efficient flight. They evolved with second most speciose group among mammals, species ca. 1400 species (Simmons \& Cirranello 2020). Bats shows similar diversification in several aspects such as distribution (except the Antarctic and few oceanic islands), body form (tiny $2 \mathrm{~g}$ upward to 1 kilogram) and enhance their 
adaptive radiation in the earth's environment (Fleming 1995, Kunz \& Lumsden 2003). The evolutionary biology of bats identified the common ancestral origin of the bat's dates back to ca. 70 million years ago, but they showed rapid change by the end of the 37 mya. Bats are found an example of the most rapid radiation in mammalian evolution (Teeling et al. 2005). Bats are providing huge ecosystem services in our environment. Seventy percent of bat consume and control huge mass of nocturnal insects in nature. Around 200 species of the bats are vegetarian that feed on nectar, pollen, ripe fruits and plant twigs. Both insect feeding bats and frugivore bats lives in anthropogenic environment and contributes for ecological balance. Bats are controlling crop pest, insect vectors of human disease and also contributing for pollination and seed dispersal of economically and ecologically important crops (Bumrungsri et al. 2009, Kunz et al. 2011). While doing so, the bats visit to the human houses, fruit orchards and water resources and shares the habitat with human and other animals. Studies has confirmed that the bats body is also serving as the natural reservoir for several zoonotic diseases (viruses, bacteria) with public concern, hence the bats conservation is important for public health security as well (Schneeberger \& Voigt 2016). The unique body features, ecology and rapid evolutionary radiation are often assumed to suit in harboring varieties of microbes of public health concern.

\section{2 | Methods}

A literature search was conducted using PubMed for this review. In order to refine the search, the following key words were incorporated: "Bat viruses" or "Zoonosis". Any article that were found in other languages besides English were excluded. The bat bushmeat hunting practice in Nepal is confirmed through solid evidences obtained during opportunistic survey of bats in various parts of Nepal. COVID-19 data were obtained from the Epidemiological Disease Control Division (EDCD), under the Ministry of Health and Population, Government of Nepal. Potential risk of viral outbreak and the preventive measures to avoid bat borne viral disease is recommended.

\section{3 | Results and discussion}

\section{1 | Bats and reservoir host}

Emerging infectious diseases cause a significant threat to human and animal health. Zoonotic diseases are an animal originated disease that spoils public health. Almost $60 \%$ of emerging infectious diseases are zoonotic (Jones et al. 2008, Luis et al. 2013). Human-animal interaction is unavoidable as they provided food, fiber, livelihood, transportation, sport, companionship, and education to peoples. Hence, human contact with animals is every day through direct or indirect ways. Wild animals are reservoir hosts for several bacteria and viruses. Epidemiological findings often claim bats to be the most favorable host for several viruses due to unique features- bats are active creature, as they possess more efficient and fascinating flight ability (Hedenström \& Johansson 2015). Moreover, bats are unique among mammals that can go for hibernation and survive with a wide range in body temperature compare to other mammals. An experiment measured a $2-6{ }^{\circ} \mathrm{C}$ increase of body temperature during a powerful flight. They can even migrate for several miles. These evolutionary features are believed to make bat as an important reservoir of several viruses (Calisher et al. 2006).

\section{2 | Important zoonotic bat viruses}

Most of the viruses are transmitted from bats to humans through an intermediate host and cause fatal outcomes. The first detection of bats as carriers of viruses came during the 1920s when the rabies virus was identified in bats in South and Central America. Till now, rabies viruses still found in bats. There is a higher risk of bat viruses to human and animal health. Most of the bat-borne virus outbreaks are an effect of human activities including habitat loss of bat.

\subsection{1 | Filoviruses (Marburg and Ebola virus)}

In 1967, a hemorrhagic fever epidemic was observed in laboratory workers of Germany and Serbia. The hemorrhagic fever in humans and other primates was caused by filoviruses. It was transmitted from African green monkeys sent from Uganda to Europe (lenczka \& Klenk 2007). The virus was named as Marburg virus for the city in Germany where the disease was first recognized. The field evidence suggested that bats might be associated with the Marburg virus. In 1976, a series of fatal hemorrhagic fevers occurred in southern Sudan. Immediately a similar disease was observed in humans in Zaire. Ebola virus was named after a river near the epidemic site in Zaire where the virus was isolated and characterized. Ebola is the deadliest viruses that affect the human being. Ebola virus RNA has been identified in a number of fruit bat from Gabon and Democratic Republic of Congo (Leroy et al. 2005). Bats maintain viruses without clinical signs of disease. Bats have developed the ability to coexist with 
different viruses; some of these viruses are lethal in other mammalian hosts. The destruction of feeding and roosting habitats caused by agricultural expansion has forced bats into urban and farming areas, creating negative interactions between bats, humans, and animals. The deforestation of bat habitat in Malaysia (1997-1998) caused bats to enter into pig farming and fruit growing. In those areas, the Nipah virus transmitted from bats to pigs to humans with fatal outcomes (Chua et al. 2002a).

\subsection{2 | Rubulaviruses (Menangle virus)}

Menangle virus was first identified in a disease outbreak in 1997 from piglets near Menangle in Australia (Philbey et al. 1998). Menangle virus is closely related epidemiologically to the Henipaviruses (Hendra and Nipah). The virus showed zoonotic in nature. Two of 250 humans in contact with the infected pigs had high titers of antibodies to this virus, but neither had direct exposure to bat (Chant et al. 1998). Fruit bats were found to be the reservoir host of Menangle virus (Philbey et al. 1998).

\subsubsection{Henipaviruses (Handra and Nipah viruses)}

In 1994, an outbreak of an acute respiratory illness occurred in a human and 14 horses in Brisbane, Australia. Twenty-one horses and two humans were infected (Murray et al. 1995). In other outbreaks (1994, 1999, and 2004), horses (5) and humans (2) get infected with killing all horses and one human (Field et al. 2000). Hendra virus was found the etiologic cause of that (Murray et al. 1995). The natural hosts and probable reservoirs host of this virus are fruit bats. It was believed that the horses infected by direct/indirect contact with infected bat and human's infection conveyed through direct contact with the infected horses.

Nipah virus, another paramyxovirus was isolated in 1998 from pigs and adult humans affected during a major outbreak in Malaysia and Singapore (Chua et al. 1999). In 1999, 265 human encephalitis cases and 105 fatalities were reported in Malaysia. Direct contact with infected pigs was identified as the main mode of human infection (Goh et al. 2000). Most of the humans infected in the Malaysian outbreak had a history of direct contact with pigs and were adult pig farmers (Chua et al. 1999). The bats were found to be natural reservoir hosts for Nipah virus (Chua et al. $2002 b$ ). Since 2001, sporadic outbreaks of Nipah virus-associated disease in humans have been identified in Bangladesh (Hsu et al. 2004). In Bangladesh, the human cases were not associated with disease in pigs, and there was some evidence suggesting human-to-human transmission (Hsu et al. 2004). Serologic surveys of domestic and wild animals undertaken after the 2001 and 2003 outbreaks in Bangladesh provided evidence of Nipah virus infection only in flying foxes (Hsu et al. 2004). Serologic surveillance of flying foxes in India (2003) found that $54 \%$ had neutralizing antibodies to Nipah virus. In 2001, India reported the incidence of Nipah virus infections in humans (Chadha et al. 2006).

\subsection{4 | Lyssavirus (Rabies virus)}

Rabies virus is the oldest human infectious diseases known. This is the negative sense, single-stranded RNA virus. It is detected from bats, dogs, and other mammals. In 1931, the rabies virus was isolated first time from bats. In the eastern United States, there is a strong association between the local temporal dynamics of rabies epizootics within a reservoir host species, in this case the raccoon, which serves as the regional reservoir host for a specific variant of rabies virus, and an increase in the risk of the rabies spillover to domestic cats (Gordon et al. 2004).

\subsection{5 | Coronaviruses}

Corona virus (CoV) was first isolated in 1937 from birds and reported in 1960 from human. It belongs to coronaviridae family. It appears as Solar Crown in electron microscope so named as the corona. It is a large enveloped virus containing singlestranded, positive-sense RNA with a genomic length of approx. 27-32 kb (Lu et al. 2020). The viral envelope consists of at least three structural proteins: The membrane protein $(\mathrm{M})$ and the envelope protein $(E)$ are involved in the virus assembly whereas the spike protein (S) mediates virus entry into host cells (Li 2016). It was associated to cause disease in both humans and animals. The report suggested that more than $80 \%$ of its infection occurs as a zoonotic disease. Till date, seven types of human corona viruses (HCoV-OC43,HCoV-HKU1, HCoV-229E, HCoV-NL63, SARS-COV, MERS-COV, and SARS-COV-2) had already reported (Li 2016)

Late 2002, the global epidemic of severe acute respiratory syndrome (SARS) caused the death of approximately 800 people. Initial efforts to identify the natural reservoir of the responsible SARS-CoV focused on palm civets, which had been sold in live animal markets in the Guangdong province in southern China. Subsequent research demonstrated that civets were an amplifying host. The true reservoir host of the SARS-like CoV were bats of the genus Rhinolophus (Li et al. 2005). The other CoV responsible for causing acute respiratory illness is named 
Middle East Respiratory Syndrome (MERS) (Bermingham et al. 2012). Genome sequencing of this virus showed that it was most closely related to a bat CoV (van Boheemen et al. 2012). The identification of a highly similar MERS-like CoV from the feces of South Africa bats suggests bats may also be a natural reservoir for the MERS-CoV (Ithete et al. 2013), but there was no direct evidence has identified the route of transmission from bats to humans.

\section{3 | Bat's bush-meat and Nepal's vulnerability}

In Nepal, around 53 species of bats from seven different orders have been reported (Acharya et al. 2010). As in the global proportion, the majority of these bats are insectivorous followed by frugivorous. Bat bush-meat culture has been confirmed among indigenous communities known as Chepang (Fig. 1 A) (Acharya et al. 2015). Bats were hunted at flowering patches of the butter plant (Dipklonema butyraceae) in central Siwalik Hills of Nepal by this community. Medium sized fruit bats (Rousettus leschenaultii) and nectar bats (Eonycteris spelaea) are the preferred choice for hunting). Chepang, Chiuri and Chamera is a popular anecdote to describe the ethnobiological interconnection in Chepang
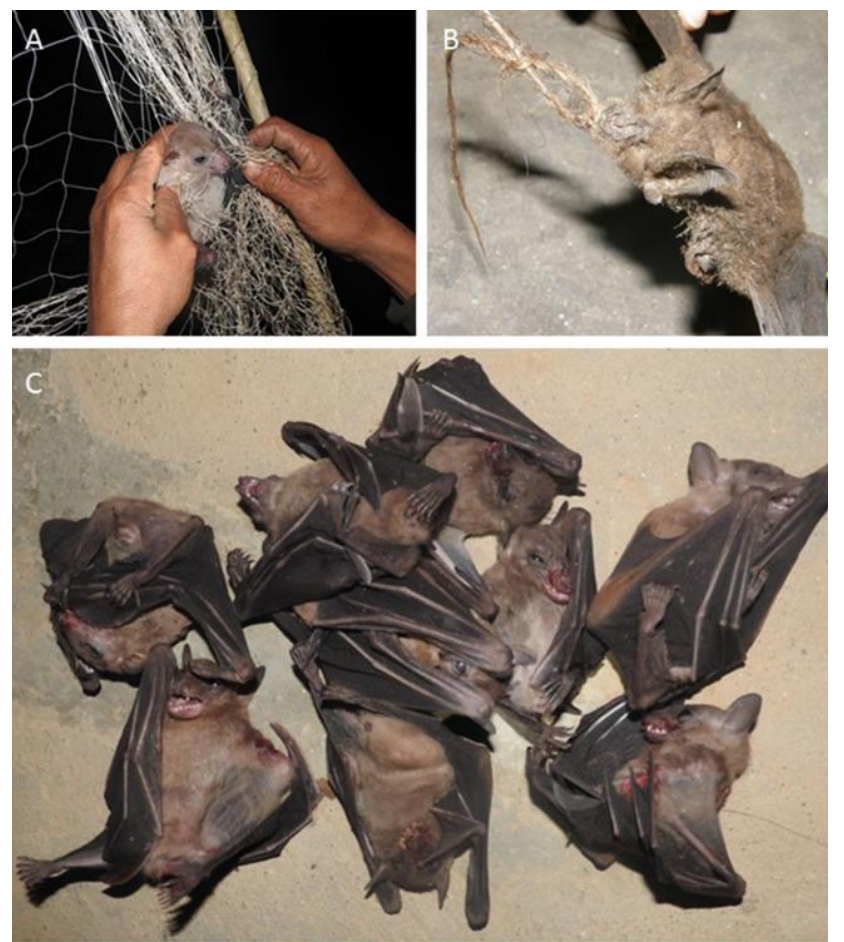

Figure 1. A: Bat hunting practice using local handmade net called bhuwa at flowering patch of Dipklonema butyraceae in Charkilla community forest, Korak VDC, Chitwan. The bat is Rousettus leschenaultii, a medium sized fruit bat. B: A dried bat Rhinolophus sp. found at a home in Taplejung, 2010. C: The bat bushmeat brought by the locals at home of Eastern Chitwan Village to process for feeding. community of Nepal (Acharya, 2015). A dried Rhinolophus sp. and myotis sp. was found at home of Limbu community at Taplejung district (Fig. 1 B and C) during bats survey at eastern Himalaya in support of Critical Ecosystem Partnership Fund, WWF (Acharya et al. 2010). Similar hunting evidence has been reported for Pteropus giganteus at Terai parts of Nepal. Bat meat is considered as a medicine around Kathmandu valley by different tribes of Newar communities (Tuladhar-Douglas 2008).

Although, there is no evidence of any sort of disease outbreak due to bat's bush-meat consumption, the bat species they consumed are recorded to be viral reservoir Rousettus. leschenaultii and $E$. spelaea were reported for a para-influenza virus, Uganda S virus, and Issyk-kul Phnom-Penh bat virus, (Keterah virus). In low land of Terai, people often noted feeding on $P$. giganteus which is reported for Australian bat lyssavirus in Malaysia and Nipah virus from India and Bangladesh (Chadha et al. 2006). Fruit-eating bat could be contaminated by the saliva, urine, and feces of bats which may contain SARS-CoV, MERSCoV, and Nipah viruses. Those plants are eaten by domestic and wild animals. When contact with those animals, humans get those viral diseases. Besides, when people enter the bat roosts with a bared foot, there is a chance to contaminate with fecal and urine of bats. If the people captured bats and tortured due to negligence, they may be bitten accidentally and transmit pathogens.

Epidemiological research evident Rhinolophus bats are potential for several viruses including corona viruses. Nepal is home to nine species of Rhinolophus. Of them, the $R$. affinis or $R$. sinicus and $R$. ferremequinum share paleotropic distribution. Be noted that coronavirus SARS-CoV in 2003 was reported from $R$. sinicus and $R$. affinis bats. These bats found in mid-hill to mountain region and often visit human houses at night. Nepal is high risk for rabies virus and one of the potential sources could be a bat (Shah et al. 2019). So, there is a very high chance of the spread of viral diseases in the community due to direct or indirect contact with bats. Tiny negligence knowingly or unknowingly will cause a great cost for public health. Now and onwards, precaution should be adopted as lessons learned from the COVID-19 pandemic.

\section{4 | COVID-19: viral alarm for Nepal}

Severe acute respiratory syndrome coronavirus-2 (SARS-CoV-2) is the causative agent of the ongoing coronavirus disease-2019 (COVID-19) pandemic. It has infected over 56 million people and 
claimed 1.3 million lives globally as of $18 / 11 / 2020$ ("Wordometer.info" 2020). Its clinical spectrum and transmission dynamics are still unclear and often unpredictable. Currently, Nepal is also alarmed due to COVID-19. The first case of SARSCoV-2 was reported on January 23, 2020, in a student who returned from Wuhan, China. The first COVID-19 sample had sent to aboard for definitive diagnosis. After the first case, the government of Nepal started molecular diagnosis system within country, trained the health worker and disseminate information by public broadcasts. To control COVID-19, government of Nepal (GoN) closed all the schools in March 19, 2020 although there had no active cases. Second COVID-19 case (March 23, 2020) was reported from a person return back from Europe. In response, Nepal closed international borders and imposed national lockdown till June 14, 2020. Within few days, nine imported COVID-19 cases were reported. In April 4, 2020, the first local cases were reported in Nepal. After that, COVID-19 cases were rapidly increased and now reported throughout the country. According to GoN, more than $86 \%$ of COVID-19 patients in Nepal had been asymptomatic. The remaining patients were mostly mild and some of them required ICU and ventilator facilities.

A total of 212,917 cases have been confirmed by real timepolymerase chain reaction (RT-PCR) with 1259 deaths November 18, 2020, in Nepal (Fig. 2). The RT-PCR positive rates for COVID19 were around $13 \%$. It took 105 days to reach the first 100 cases on 08/05/2020, while cases were subsequently increased to 1042 (>10-fold increase) within 42 the next 20 days and to 10,000 cases in the following 26 days. The government response stringency index was $100 \%$ (strictest response) based on nine response indicators including schools' closures, workplace

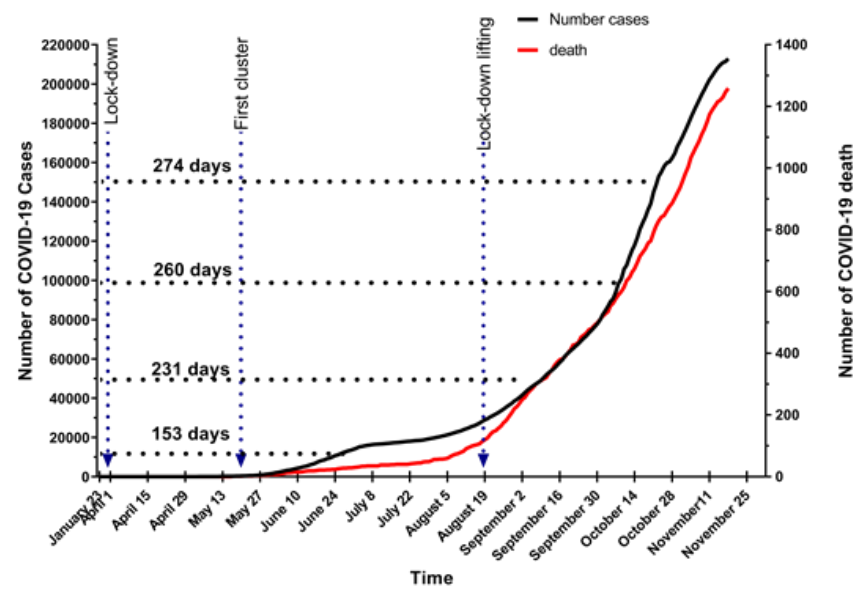

Figure 2. Trends of COVID-19 cases and deaths in Nepal closures. Regardless of such stringency, the total confirmed cases of COVID-19 in Nepal in the past several weeks are increasing exponentially. The GoN had made progress in number of testing center from 1 to 74 in the past few months. Both the government and private hospitals are provided dedicate space with isolation facilities for COVID-19 patients.

\section{4 | Conclusions}

Although COVID-19 transmission is human to human, it is believed to be originated from wild animals probably from bats. Hence, Nepal should not ignore bat and associated viral mobility. The intermediary host has been mentioned for the viral mutation before human infestation of bat viruses. Since other wildlife mammals including rodents, pigs, pangolin are reported time to time, we need to establish surveillance to monitor the presence of viruses in the bat and these mammals. Bats ecology and ranging behavior are important as it relates to disease dispersal in human-wildlife interface. Regular monitoring of bat colonies for the viral and bacterial examination will help for proper public awareness and precaution measures. This requires further study to understand host-virus interaction and consequent mutation. One health concept is a very important to approach for preventing and controlling the emerging and re-emerging diseases. An interdisciplinary effort among different fields of expertise such as zoology, molecular biologist, microbiologist, chemist, and sociologist is needed for the study of bat-origin viruses. Public notice as well as public awareness programs will be adopted to ensure bat conservation as well as public health safety.

\section{Acknowledgements}

The authors would like to thanks to CEPF WWF Nepal for providing a bat project at Kanchenjungha-Singhalila complex of eastern Himalaya. We would like to thanks Epidemiology and Diseases Control Division for providing COVID-19 data. Acharya has got a small grant award in 2015 from Rufford Foundation to execute the project fruit bat conservation initiative to carry conservation survey at chepang community. We would like to thanks to the students of the Institute of Forestry Ms. Neha Shahi, Bidhya Sharma Arjun Rijal and Raj Prasai for their assistance during the field surveyor bat hunting assessment at Chitwan and Makawanpur districts. Mr. Sanjan Thapa and Dipa Wasti are acknowledged for her assistance during CEPF Bat Project in the eastem Himalaya. We are grateful to our anonymous reviewer for helping to improve the manuscript. 


\section{Authors' contributions}

Both the authors designed the study, analyzed the data and wrote the manuscript.

\section{Conflicts of interest}

Authors declare no conflict of interest.

\section{ORCID}

Pushpa Raj Acharya (D) https://orcid.org/0000-0003-3439-8267 Kishor Pandey (D) https://orcid.org/0000-0002-0619-9108

\section{References}

Acharya, P. R., Adhikari, H., Dahal, S., Thapa, A. and Thapa, S. 2010. Bats of Nepal. A field guide. Small Mammals Conservation and Research Foundation (SMCRF), Kathmandu, p 116.

Acharya, P. R., Racey, P. A., Sotthibandhu, S. and Bumrungsri, S. 2015. Feeding behaviour of the dawn bat (Eonycteris spelaea) promotes cross pollination of economically important plants in Southeast Asia. Journal of Pollination Ecology 15:44-50 https://doi.org/10.26786/1920-7603(2015)5

Acharya, P. R. 2015. Chepang, Chiuri and Chamera, a Conservation Handbook. Friends of Nature (FoN), Kathmandu, p 32.

Anderson, R. M. and May, R. M. 1992. Indirectly transmitted microparasites, in: Infectious Diseases of Humans: Dynamics and Control. Oxford University Press.

Bermingham, A., Chand, M.A., Brown, C. S., Aarons, E., Tong, C., Langrish, C., et al. 2012. Severe respiratory illness caused by a novel coronavirus, in a patient transferred to the United Kingdom from the Middle East, September. Euro surveillance 17:20290 https://doi.org/10.2807/ese.17.40.20290-en

Bumrungsri, S., Sripaoraya, E., Chongsiri, T., Sridith, K. and Racey, P. A. 2009. The pollination ecology of durian (Durio zibethinus, Bombacaceae) in southern Thailand. Journal of Tropical Ecology 25:85-92. https://doi.org/10.1017/S0266467408005531

Calisher, C. H., Childs, J. E., Field, H. E., Holmes, K. V. and Schountz, T. 2006. Bats: Important reservoir hosts of emerging viruses. Clinical Microbiology Review 19:531-545. https://doi.org/10.1128/CMR.00017-06

Chadha, M. S., Comer, J. A., Lowe, L., Rota, P. A., Rollin, P. E., Bellini, W. J., et al. 2006. Nipah virus-associated encephalitis outbreak, Siliguri, India. Emerging Infectious Diseases 12:235-240 https://doi.org/10.3201/eid1202.051247

Chant, K., Chan, R., Smith, M., Dwyer, D. E., Kirkland, P., Conaty, S., et al. 1998. Probable human infection with a newly described virus in the family Paramyxoviridae. Emerging Infectious Diseases 4:273-275. https://doi.org/10.3201/eid0402.980215

Chua, K. B., Chua, B. H. and Wang, C. W. 2002a. Anthropogenic deforestation, El Niño and the emergence of Nipah virus in Malaysia. The Malaysian Journal of Pathology 24:15-21.

Chua, K. B., Goh, K. J., Wong, K. T., Kamarulzaman, A., Tan, P. S. K., Ksiazek, T. G., et al. 1999. Fatal encephalitis due to Nipah virus among pig-farmers in Malaysia. Lancet. 354:1257-1259. https://doi.org/10.1016/S0140-6736(99)04299-3

Chua, K. B., Lek Koh, C., Hooi, P. S., Wee, K. F., Khong, J. H., Chua, B. H., et al. 2002b. Isolation of Nipah virus from Malaysian Island flying-foxes. Microbes and Infections 4:145-451. https://doi.org/10.1016/S1286-4579(01)01522-2

Drexler, J. F., Corman, V. M., Müller, M. A., Maganga, G. D., Vallo, P., Binger, T., et al. 2012. Bats host major mammalian paramyxoviruses. Nature Communications 3:796. https://doi.org/10.1038/ncomms1796

Field, H. E., Barratt, P. C., Hughes, R. J., Shield, J. and Sullivan, N. D. 2000. A fatal case of Hendra virus infection in a horse in north Queensland: Clinical and epidemiological features. Australian Veterinary Journal 78:279-280. https://doi.org/10.1111/j.17510813.2000.tb11758.x

Fleming, T. H. 1995. Walker's Bats of the World. Ronald M. Nowak. The Quartely Review of Biology 70:517. https://doi.org/10.1086/419211

Goh, K. J., Tan, C. T., Chew, N. K., Tan, P. S. K., Kamarulzaman, A., Sarji, S. A., et al. 2000. Clinical features of Nipah virus encephalitis among pig farmers in Malaysia. The New England Journal of Medicine 342:1229-1235. https://doi.org/10.1056/NEJM200004273421701

Gordon, E. R., Curns, A. T., Krebs, J. W., Rupprecht, C. E., Real, L. A. and Childs, J. E. 2004. Temporal dynamics of rabies in a wildlife host and the risk of cross-species transmission. Epidemiology and Infection 132:515-524. https://doi.org/10.1017/S0950268804002067

Guo, W. P., Lin, X. D., Wang, W., Tian, J. H., Cong, M. L., Zhang, H. L., et al. 2013. Phylogeny and Origins of Hantaviruses Harbored by Bats, Insectivores, and Rodents. PLoS Pathogens 9:e1003159. https://doi.org/10.1371/journal.ppat.1003159

Hayman, D. T. S. 2016. Bats as Viral Reservoirs. Annual Review of Virology 3:77-99. https://doi.org/10.1146/annurev-virology-110615-042203

Hedenström, A. and Christoffer Johansson, L. 2015. Bat flight: Aerodynamics, kinematics and flight morphology. The Journal of Experimental Biology 218:653-663. https://doi.org/10.1242/jeb.031203 
Hsu, V. P., Hossain, M. J., Parashar, U. D., Ali, M. M., Ksiazek, T. G., Kuzmin, I., et al. 2004. Nipah virus encephalitis reemergence, Bangladesh. Emerging Infectious Diseases 10:2082-2087. https://doi.org/10.3201/eid1012.040701

Ithete, N. L., Stoffberg, S., Corman, V. M., Cottontail, V. M., Richards, L. R., Schoeman, M. C., et al. 2013. Close relative of human middle east respiratory syndrome coronavirus in bat, South Africa. Emerging Infectious Diseases 19:1697-1699. https://doi.org/10.3201/eid1910.130946

Jones, K. E., Patel, N. G., Levy, M. A., Storeygard, A., Balk, D., Gittleman, J. L., et al. 2008. Global trends in emerging infectious diseases. Nature 451:990-993.

https://doi.org/10.1038/nature06536

Kunz, T. H., de Torrez, E. B., Bauer, D., Lobova, T. and Fleming, T. H. 2011. Ecosystem services provided by bats. Annals of the New York Academy of Science 1223:1-38. https://doi.org/10.1111/j.1749-6632.2011.06004.x

Kunz, T. H. and Lumsden, L. F. 2003. Ecology of cavity and foliage roosting bats, in: Bat Ecology. University of Chicago Press.

Leroy, E. M., Kumulungui, B., Pourrut, X., Rouquet, P., Hassanin, A., Yaba, P., et al. 2005. Fruit bats as reservoirs of Ebola virus. Nature 438:575-576. https://doi.org/10.1038/438575a

Li, F. 2016. Structure, Function, and Evolution of Coronavirus Spike Proteins. Annual Review of Virology 3:237-261.

https://doi.org/10.1146/annurev-virology-110615-042301

Li, W., Shi, Z., Yu, M., Ren, W., Smith, C., Epstein, J. H., et al. 2005. Bats are natural reservoirs of SARS-like coronaviruses. Science 310:679-679. https://doi.org/10.1126/science.1118391

Lu, R., Zhao, X., Li, J., Niu, P., Yang, B., Wu, H., et al. 2020. Genomic characterisation and epidemiology of 2019 novel coronavirus: implications for virus origins and receptor binding. Lancet 395:565-574. https://doi.org/10.1016/S0140-6736(20)30251-8

Luis, A. D., Hayman, D. T. S., O'Shea, T. J., Cryan, P. M., Gilbert, A T., Pulliam, J. R. C., et al. 2013. A comparison of bats and rodents as reservoirs of zoonotic viruses: Are bats special? Proceeding, Biological Sciences 280:20122753. https://doi.org/10.1098/rspb.2012.2753

Murray, K., Selleck, P., Hooper, P., Hyatt, A., Gould, A., Gleeson, L., et al. 1995. A morbillivirus that caused fatal disease in horses and humans. Science 268:94-97. https://doi.org/10.1126/science.7701348

Philbey, A. W., Kirkland, P. D., Ross, A. D., Davis, R. J., Gleeson, A. B., Love, R. J., et al. 1998. An apparently new virus (family Paramyxoviridae) infectious for pigs, humans, and fruit bats. Emerging Infectious Diseases 4:269-271.

https://doi.org/10.3201/eid0402.980214
Rott, R. and Siddell, S. 1998. One hundred years of animal virology. The Journal of General Virology 79:2871-2874. https://doi.org/10.1099/0022-1317-79-11-2871

Schneeberger, K. and Voigt, C. C. 2016. Zoonotic viruses and conservation of bats. In Bats in the Anthropocene: conservation of Bats in a Changing world (pp. 263-292). Springer, Cham.

Simmons, N. B. and Cirranello, A. L. 2020. Bat Species of the World: A taxonomic and geographic database. Accessed on 12/17/2020 Shah, Y., Pandey, K., Pant, D. K., Poudel, A., Dahal, B., Panta, K. P., et al. 2019. Potential Threat of Rabies Virus from Bat Bite in Nepal. The Open Microbiology Journal 12:419-421. https://doi.org/10.2174/1874285801812010419

Shostak, A. W., 2003. The Ecology of Wildlife Diseases. Journal of Wildlife Diseases 39:470-471. https://doi.org/10.7589/0090-3558-39.2.470

Slenczka W, and Klenk H. D. 2007. Forty years of marburg virus. Journal of Infectious Diseases 15(196):S131-135. https://doi.org/10.1086/520551

Smith, C., Skelly, C., Kung, N., Roberts, B. and Field, H. 2014. Flyingfox species density - A spatial risk factor for Hendra virus infection in horses in eastern Australia. PLoS One 9:e99965. https://doi.org/10.1371/journal.pone.0099965

Teeling, E. C., Springer, M. S., Madsen, O., Bates, P., O’Brien, S. J. and Murphy, W. J. 2005. A molecular phylogeny for bats illuminates biogeography and the fossil record. Science 307:580-584. https://doi.org/10.1126/science.1105113

Tong, S., Li, Y., Rivailler, P., Conrardy, C., Alvarez Castillo, D. A., Chen, L. M., et al. 2012. A distinct lineage of influenza A virus from bats. Proceeding of the National Academy of Sciences of the United States of America 109:4269-4274. https://doi.org/10.1073/pnas.1116200109

Tuladhar-Douglas, W. 2008. The use of bats as medicine among the Newars. Journal fo Ethnobiology 28:69-91. https://doi.org/10.2993/02780771(2008)28[69:TUOBAM]2.0.CO;2 van Boheemen, S., de Graaf, M., Lauber, C., Bestebroer, T. M., Raj, V. S., Zaki, A. M., et al. 2012. Genomic characterization of a newly discovered coronavirus associated with acute respiratory distress syndrome in humans. MBio 3:e00473-12. https://doi.org/10.1128/mBio.00473-412

Worldometer.info [WWW Document], 2020. https://www.worldometers.info/coronavirus/, Accessed on 18 November 2020.

\section{Cite this article as:}

Acharya, P. R. and Pandey, K. 2020. Understanding bats as a host of different viruses and Nepal's vulnerability on bat viruses. Nepalese Journal of Zoology 4(2):133-139. https://doi.org/10.3126/njz.v4i2.33899 